\title{
Fluid Flow Induced Calcium Response in Bone Cell Network
}

\author{
Bo Huo ${ }^{1,2}$, Xin L. Lu ${ }^{1}$, Clark T. Hung ${ }^{3}$, Kevin D. Costa ${ }^{4}$, Qiaobing Xu ${ }^{5}$, George M. \\ Whitesides $^{5}$, and X. Edward Guo ${ }^{1}$ \\ ${ }^{1}$ Bone Bioengineering Laboratory, Department of Biomedical Engineering, Columbia University, 351 \\ Engineering Terrace, 1210 Amsterdam Avenue, Mail Code 8904, New York, NY 10027, USA \\ ${ }^{2}$ Institute of Mechanics, Chinese Academy of Sciences, Beijing 100080, P.R. China \\ ${ }^{3}$ Cellular Engineering Laboratory, Department of Biomedical Engineering, Columbia University, \\ New York, NY 10027, USA \\ ${ }^{4}$ Cardiac Cell Mechanics Laboratory, Department of Biomedical Engineering, Columbia University, \\ New York, NY 10027, USA \\ ${ }^{5}$ Department of Chemistry and Chemical Biology, Harvard University, Cambridge, MA 02138, USA
}

\begin{abstract}
In our previous work, bone cell networks with controlled spacing and functional intercellular gap junctions had been successfully established by using microcontact printing and self assembled monolayers technologies [Guo, X. E., E. Takai, X. Jiang, Q. Xu, G. M. Whitesides, J. T. Yardley, C. T. Hung, E. M. Chow, T. Hantschel, and K. D. Costa. Mol. Cell. Biomech. 3:95-107, 2006]. The present study investigated the calcium response and the underlying signaling pathways in patterned bone cell networks exposed to a steady fluid flow. The glass slides with cell networks were separated into eight groups for treatment with specific pharmacological agents that inhibit pathways significant in bone cell calcium signaling. The calcium transients of the network were recorded and quantitatively evaluated with a set of network parameters. The results showed that $18 \alpha$-GA (gap junction blocker), suramin (ATP inhibitor), and thapsigargin (depleting intracellular calcium stores) significantly reduced the occurrence of multiple calcium peaks, which were visually obvious in the untreated group. The number of responsive peaks also decreased slightly yet significantly when either the COX-2/PGE 2 or the NOS/nitric oxide pathway was disrupted. Different from all other groups, cells treated with $18 \alpha$-GA maintained a high concentration of intracellular calcium following the first peak. In the absence of calcium in the culture medium, the intracellular calcium concentration decreased slowly with fluid flow without any calcium transients observed. These findings have identified important factors in the flow mediated calcium signaling of bone cells within a patterned network.
\end{abstract}

\section{Keywords}

Bone cell; Fluid shear; Gap junction; $\mathrm{PGE}_{2}$; Nitric oxide; ATP; Calcium store 


\section{INTRODUCTION}

Osteocytes are interconnected through numerous intercellular processes, forming extensive cell networks throughout the bone tissue. ${ }^{6,36,39}$ It has been shown that osteocyte density is an important physiological parameter, which decreases with age and microdamage accumulation. ${ }^{34}$ However, most previous studies on mechanotransduction in osteocytes and osteoblasts were performed on confluent or sub-confluent uncontrolled monolayers of cells. ${ }^{38,40}$ In order to examine the roles of the cellular connectivity between bone cells in mechanotransduction, a controlled bone cell network is necessary for quantitative studies. In our previous study, ${ }^{11} \mathrm{a}$ two-dimensional patterned bone cell network was successfully established to mimic the in vivo osteocyte network by using microcontact printing and self assembled monolayers (SAM) technologies. Each individual bone cell in the network was connected with four neighboring cells via functional gap junctions. Under applied single cell nano-indentation with an atomic force microscope probe, calcium wave propagation within the bone cell network was observed. It was also demonstrated that multiple calcium peaks observed within an individual bone cell resulted from the self-perpetuating signal propagation within the circuit of the bone cell network. One of the major objectives of the present study was to examine the spatiotemporal characteristics of the intracellular calcium response in a well-controlled bone cell network under a steady fluid flow, a more physiologically relevant stimulation mode than the nanoindentation on a single bone cell in the network.

Calcium signaling is essential for numerous bone cell functions, such as proliferation and differentiation..$^{3,15,29,41,42}$ It has been demonstrated that mechanical stimuli such as fluid flow can induce a consistent and robust intracellular calcium $\left(\left[\mathrm{Ca}^{2+}\right]_{\mathrm{i}}\right)$ response and intercellular calcium signaling in bone cells.21,28 The fluid flow induced elevation of cytosolic calcium comes mainly from two sources: intracellular stores (e.g., endoplasmic reticulum, ER) and the extracellular environment. ${ }^{4}, 14\left[\mathrm{Ca}^{2+}\right]_{\mathrm{i}}$ signaling is mediated by various molecular pathways, e.g., inositol trisphosphate $\left(\mathrm{IP}_{3}\right)$, adenosine 5'-triphosphate (ATP), prostaglandin $\mathrm{E}_{2}\left(\mathrm{PGE}_{2}\right)$, and nitric oxide (NO) (Fig. 1). $\mathrm{IP}_{3}$ can lead to a rapid release of calcium stored in the ER via binding to the ER membrane receptor.3,15 After the cytosolic calcium concentration is elevated to a critical level by intra/extracellular sources, the depleted intracellular calcium stores tend to recover their calcium reservation to original level and become ready for a next release of calcium. 3,24 When a bone cell is under fluid flow induced shear stress, the activation of gap junction hemichannels (connexin 43) induces ATP efflux from the cytosol to the pericellular environment. ${ }^{8,9}$ Extracellular ATP can elicit a significant $\left[\mathrm{Ca}^{2+}\right]_{\mathrm{i}}$ response by binding with the $\mathrm{P}_{2}$ purinergic membrane receptor. ${ }^{13}$ Fluid shear stress can also prompt the induction of COX-2 protein and further $\mathrm{PGE}_{2}$ release in MC3T3-E1 osteoblast-like cells. ${ }^{25}$ It was previously reported that fluid shear stress can elicit nitric oxide production in osteocytes and osteoblasts accompanied by an increased expression of nitric oxide synthase (NOS) ${ }^{23,40}$ Nitric oxide modulates $\left[\mathrm{Ca}^{2+}\right]_{\mathrm{i}}$ signaling via a cyclic guanosine monophosphate (cGMP) dependent pathway 22 or nitrosylation of proteins. 35 Moreover, nitric oxide could directly contribute to the $\left[\mathrm{Ca}^{2+}\right]_{\mathrm{i}}$ release via triggering of an influx pathway that is, in part, responsible for the refilling of internal calcium stores. ${ }^{20}$

Gap junctions are membrane-spanning channels, where each pair of connexons (i.e. hemichannels) forms a cylinder with a pore in the center through which small molecules $(<1$ $\mathrm{kDa}$ ) can pass from one cell to another cell. ${ }^{31}$ It is widely accepted that this intercellular connection plays a significant role in coordinating bone cell network activities. Messenger molecules mentioned previously, such as $\mathrm{IP}_{3}$ and calcium, may be able to transfer between the neighboring cells through gap junctions and thereby mediate propagation of $\left[\mathrm{Ca}^{2+}\right]_{\mathrm{i}}$ signaling in bone cells. ${ }^{17,38}$ The quantitative description of $\left[\mathrm{Ca}^{2+}\right]_{\mathrm{i}}$ signaling within a controlled bone cell network connected by gap junctions under fluid shear has yet to be obtained experimentally. 
In the present study, using microcontact printing and SAM technologies developed previously, ${ }^{11}$ bone cell networks with controlled spacing and functional intercellular gap junctions were built with MC3T3-E1 osteoblast-like bone cells. The cell networks were divided into 8 groups to test the effects of treatment with a battery of pharmacological agents to interrupt or inhibit $\left[\mathrm{Ca}^{2+}\right]_{\mathrm{i}}$ signaling. The $\left[\mathrm{Ca}^{2+}\right]_{\mathrm{i}}$ responses of the networks under steady fluid flow were recorded with fluorescence images, and the spatiotemporal characteristics of the $\left[\mathrm{Ca}^{2+}\right]_{i}$ responses were quantitatively characterized with a set of network parameters, such as number of calcium spikes, time to reach first peak, and time to 50\% relaxation. The inter/intra cellular calcium signaling mechanisms and the roles of different molecular pathways in $\left[\mathrm{Ca}^{2+}\right]_{\mathrm{i}}$ signaling were further analyzed.

\section{MATERIALS AND METHODS}

\section{Bone Cell Network}

Microcontact printing and SAM surface chemistry technologies were used to prepare the bone cell networks as described previously. ${ }^{11}$ In brief, a chromium mask containing the desired square grid of connected circles was fabricated. The pattern was replicated to a master made of Shipley 1818 positive photoresist (MicroChem Corp, Newton, MA) by exposing it to UV light through the mask. The geometric parameters of the pattern adopted here ( $2 \mu \mathrm{m}$ width connection line, $20 \mu \mathrm{m}$ diameter circle, and $70 \mu \mathrm{m}$ separation distance) were optimized for osteoblast-like cells. ${ }^{11}$ A polydimethylsiloxane (PDMS, Sylgard 184, Dow Corning, Midland, MI) stamp with the desired micropattern was then generated by curing PDMS elastomer on the master. On the day before the fluid flow experiment, the stamp was coated with an adhesive SAM (octadecanethiol; Sigma-Aldrich Co., St. Louis, MO), and pressed onto a gold-coated glass slide (150 ̊ Au using an e-beam evaporator, SC2000, SEMICORE Inc., Livermore, CA) for $60 \mathrm{~s}$. The stamped glass slide was immediately immersed in a non-adhesive ethylene glycol terminated SAM solution (HS-C11-EG3; Prochimia, Sopot, Poland) for $3 \mathrm{~h}$ to cover areas that were not patterned with the adhesive SAM. To facilitate cell adhesion, the patterned slide was further incubated in $10 \mu \mathrm{g} / \mathrm{mL}$ fibronectin (Sigma-Aldrich Co., St. Louis, MO) in PBS for 1 $\mathrm{h}$, which can only be absorbed by the adhesive SAM coated region. Osteoblast-like MC3T3E1 cells with controlled density $\left(1.0 \times 10^{4} \mathrm{cell} / \mathrm{cm}^{2}\right)$ were seeded on the patterned slide and cultured in $\alpha$-MEM medium supplemented with $2 \%$ charcoal-stripped fetal bovine serum (CSFBS, Hyclone Laboratories Inc., Logan, UT) for $24 \mathrm{~h}$ before further testing. CS-FBS was used here to control the growth of cells and to avoid double-cell-occupancy on a single circular spot on the pattern. Figure 2 shows the snapshots of a typical bone cell network in the untreated group with a $70 \mu \mathrm{m}$ separation distance.

\section{Steady Fluid Flow and $\left[\mathrm{Ca}^{2+}\right]_{\mathrm{i}}$ Response}

To indicate $\left[\mathrm{Ca}^{2+}\right]_{\mathrm{i}}$, patterned bone cells on the glass slide were loaded with $5 \mu \mathrm{M}$ Fluo-4 AM (Molecular Probes, Eugene, OR) in $\alpha$-MEM medium supplemented with $0.5 \%$ CS-FBS for 1 $\mathrm{h}$ at $37^{\circ} \mathrm{C}$. After calcium dye loading, the slide was rinsed with dye-free medium twice and then mounted on a custombuilt parallel plate flow chamber, which was attached to an inverted fluorescence microscope (Olympus IX71, Melville, NY) with a 10x objective. ${ }^{14}$ The entire operation was performed with extreme care to minimize the response of cells to early agitations. Furthermore, a 20-min resting period preceded fluid flow stimulation, which has been shown to be sufficient for bone cells to recover and to generate repetitive $\left[\mathrm{Ca}^{2+}\right]_{\mathrm{i}}$ responses. ${ }^{10} \mathrm{~A}$ magnetic gear pump was connected to the chamber to generate a steady fluid flow with a constant shear stress of $40 \mathrm{dyne} / \mathrm{cm}^{2}$ on the cell surface. The $\left[\mathrm{Ca}^{2+}\right]_{\mathrm{i}}$ response of the bone cell network under fluid flow stimulation was recorded with a high-speed CCD camera (ORCAER-1394, Hamamatsu Photonics K.K., Hamamatsu City, Japan) for a total 10-min period, 1 $\min$ for baseline and $9 \mathrm{~min}$ after the onset of fluid flow. The intensity of $\left[\mathrm{Ca}^{2+}\right]_{\mathrm{i}}$ for each cell was later normalized by its corresponding baseline. 


\section{Experimental Groups}

Besides the untreated group (12 slides, 130 cells analyzed), seven specific biochemical blocking agents were employed to identify the sources and the contributions of molecular pathways to the network characteristics of $\left[\mathrm{Ca}^{2+}\right]_{\mathrm{i}}$ response. (1) Extracellular calcium depletion: In this group, calcium-free Dulbecco's Modified Eagle Medium (DMEM, Invitrogen Corporation, Carlsbad, CA) and calcium-free Hank's Balanced Salt Solution (HBSS, Invitrogen Corporation) were introduced to replace the regular medium after Fluo-4 AM loading (8 slides, 99 cells analyzed). (2) ER calcium store depletion: After Fluo-4 staining, the cell-seeded slides (6 slides, 90 cells analyzed) were incubated in $1 \mu \mathrm{M}$ Thapsigargin (TG) (Sigma-Aldrich Co.) medium for 30 min prior to flow. ${ }^{13}$ TG depletes calcium from the ER store. (3) $P G E_{2}$ blocking: The patterned cells were pretreated with $10 \mu \mathrm{M} \mathrm{N}-(2-$ cyclohexyloxy-4-nitrophenyl)methanesulfonamide (NS-398, EMD Chemicals Inc., San Diego, CA) for $24 \mathrm{~h}$ before flow study. NS-398 selectively inhibits the COX-2 enzyme activity, which in turn blocks the $\mathrm{PGE}_{2}$ release. ${ }^{25}$ One hundred and twenty-three cells on 11 slides were analyzed in this group. (4) NO blocking: In this group, $100 \mu \mathrm{M}$ NG-monomethyl-L-arginine (L-NMMA; EMD Chemicals Inc.) was introduced into the cell culture medium 1 day before seeding the cells on slides and continuously presented in mediums afterward. L-NMMA inhibits the production of nitric oxide via competitively inhibiting all three isoforms of nitric oxide synthase (NOS). ${ }^{27}$ In this group, 189 cells on 16 slides were analyzed. (5) Gap junction blocking: To study the role of intercellular gap junctions on calcium responses of the bone cell network, $75 \mu \mathrm{M} 18 \alpha$-Glycyrrhetinic acid (18 $\alpha$-GA, Sigma-Aldrich Co.), a reversible gap junction blocker which binds to membrane proteins and causes disassembly of gap junction plaques, 12 was supplied in Fluo-4 AM loading medium and fluid flow medium. ${ }^{38}$ In this group, 61 cells on 6 slides were studied. (6) ATP blocking: Suramin (EMD Chemicals Inc.), a P2 purinergic receptor blocker, was employed to investigate the effect of ATP release on the $\left[\mathrm{Ca}^{2+}\right]_{\mathrm{i}}$ response. $100 \mu \mathrm{M}$ suramin was applied to the cells $30 \mathrm{~min}$ before exposing to shear flow. ${ }^{37}$ Fifty cells from 3 slides were analyzed. (7) Vehicle DMSO control: Among all the previously employed chemicals, NS-398, 18 $\alpha$-GA, and TG were dissolved into DMSO.

Therefore vehicle control testing was performed with $0.3 \%(\mathrm{v} / \mathrm{v})$ DMSO presented in medium ( 3 slides, 51 cells analyzed). The concentrations of above agents were chosen from the relevant literature in bone cells where they have been demonstrated to be effective in inhibiting their respective pathways.

\section{Data Analysis}

To quantitatively analyze the network characteristics of the $\left[\mathrm{Ca}^{2+}\right]_{\mathrm{i}}$ responses, a set of network parameters were defined from the time-lapse of $\left[\mathrm{Ca}^{2+}\right]_{\mathrm{i}}$ response (Fig. 3). For each individual cell, the total number of $\left[\mathrm{Ca}^{2+}\right]_{\mathrm{i}}$ responsive peaks during the flow stimulation period was counted. $t_{1}$ denoted the time between the onset point of fluid flow and the maximum value of the first responsive spike, while $t_{2}$ was the time from first peak to its $50 \%$ relaxation point. $t_{3}$, $t_{4}$, and $t_{5}$ were defined as the time intervals in between successive peaks, respectively, and $m_{1}$ is the normalized magnitude of the first peak. One-way analysis of variance (ANOVA) with Bonferroni's post hoc analysis was performed to determine statistical differences between mean values of different treatments, $p<0.05$. The condition of equal population variances of treatments was tested by Levene's method.

\section{RESULTS}

A typical set of intracellular calcium images during the testing period are shown in Fig. 2, clearly demonstrating multiple responses of bone cells within the network under fluid flow. A set of typical $\left[\mathrm{Ca}^{2+}\right]_{\mathrm{i}}$ traces of individual cells from the untreated group and those with different treatments are shown in Fig. 4. In each group, $\left[\mathrm{Ca}^{2+}\right]_{\mathrm{i}}$ profiles of three cells from a single glass slide were plotted. For untreated, vehicle control, NS-398 ( $\mathrm{PGE}_{2}$ blocking), and L-NMMA 
(NO blocking) groups, multiple $\left[\mathrm{Ca}^{2+}\right]_{\mathrm{i}}$ responsive peaks were quite obvious even by visual inspection. However, 18 $\alpha$-GA (gap junction blocking) and TG (ER calcium depletion) groups tended to exhibit only a single $\left[\mathrm{Ca}^{2+}\right]_{i}$ peak. In the $18 \alpha$-GA group, it was interesting to note that the $\left[\mathrm{Ca}^{2+}\right]_{\mathrm{i}}$ intensity was sustained at a relatively high level after the first calcium peak. In the absence of extracellular calcium, unlike the $\left[\mathrm{Ca}^{2+}\right]_{\mathrm{i}}$ response in any other group, $\left[\mathrm{Ca}^{2+}\right]_{\mathrm{i}}$ decreased slowly after the onset of fluid flow without any $\left[\mathrm{Ca}^{2+}\right]_{\mathrm{i}}$ peak.

To quantitatively and statistically analyze the calcium waves, the frequencies of multiple responding peaks are shown in Fig. 5a, while the mean value of the number of responding peaks are plotted in Fig. 5b. In the untreated group, over 55\% of cells were able to respond three or more times with an overall mean value as $2.89 \pm 0.16$ times of baseline. In the vehicle control group, this value was $2.33 \pm 0.19$ but no significant difference was detected when compared with the untreated group. Both NS-398 $\left(\mathrm{PGE}_{2}\right.$ blocking) and L-NMMA (NO blocking) resulted in fewer multiple responses, only $50 \%$ of cells exhibited two or more calcium transients. Furthermore, 15 and $22 \%$ of cells had no response to fluid flow in these two groups, respectively, which was significantly higher than those of the untreated or vehicle control group. 18 $\alpha$-GA (gap junction blocking) and suramin (ATP blocking) significantly reduced the number of calcium peaks, while cells with a single response comprised approximately $60 \%$ of the total population. ANOVA testing revealed no significant difference between the mean values of these two groups, but they were both significantly different from untreated and vehicle control groups. The TG-treated group (ER depleted) generated the least number of responding calcium peaks, which was significantly different from any other group. The removal of extracellular $\mathrm{Ca}^{2+}$ completely abolished the $\left[\mathrm{Ca}^{2+}\right]_{\mathrm{i}}$ response.

As shown in Fig. 6, cells in the gap junction blocked group took the longest time to reach the first $\left[\mathrm{Ca}^{2+}\right]_{\mathrm{i}}$ peak $\left(t_{1}=61 \pm 7 \mathrm{~s}\right)$. Moreover, the relaxation time of this group was nearly 5 times that of all other groups $\left(t_{2}=222 \pm 23 \mathrm{~s}\right)$. The untreated and TG groups shared a similar $t_{1}$ value (40 \pm 4 vs. $34 \pm 2 \mathrm{~s}, p>0.05$ ). The vehicle control, NS-398, L-NMMA, and suramin groups all had significantly shorter first peak response times when compared with the untreated group, but there was no significant difference among these four groups. Aside from the $18 \alpha$-GA group, all the other six groups had no significant difference in the $50 \%$ relaxation time. The $18 \alpha$-GA group was further characterized with the highest first peak magnitude $\left(m_{1}=267 \pm 22 \%\right.$ of baseline). The NS-398 and L-NMMA groups also had slightly yet significantly higher $m_{1}$ values than those of the other three groups. When comparing the time intervals between calcium peaks, i.e. $t_{3}, t_{4}$, and $t_{5}$, it was found that only the $18 \alpha$-GA group had significantly higher $t_{3}$ value than the untreated or L-NMMA group. The mean values of these time intervals fell within the range of 100-200 s.

\section{DISCUSSION}

The network characteristics of $\left[\mathrm{Ca}^{2+}\right]_{\mathrm{i}}$ response of bone cells in a controlled cell network have been quantified, and several biochemical pathways related to $\left[\mathrm{Ca}^{2+}\right]_{i}$ signaling have been examined. Notably, multiple $\left[\mathrm{Ca}^{2+}\right]_{i}$ peaks, a signature of network circuits, have been observed in bone cell networks under applied steady fluid flow. Intracellular calcium signaling in bone cells involves both internal and external sources of calcium. ${ }^{3}$ The internal calcium stores are mainly held within the membrane systems of the ER. ${ }^{2,5}$ Current experimental results from calcium-free media and ER depletion groups have identified the calcium source underlying the $\left[\mathrm{Ca}^{2+}\right]_{\mathrm{i}}$ responses in the bone cell networks. The cells in calcium-free media showed absolutely no $\left[\mathrm{Ca}^{2+}\right]_{\mathrm{i}}$ increase due to fluid flow, indicating the critical role of extracellular calcium. A few researchers have noted that the influx of extracellular calcium is required to evoke the opening of the calcium release channels in the ER. ${ }^{18,24}$ In fact, it has been shown that the gap junction dependent propagation of intercellular calcium signals in rat osteoblast cells requires influx of external calcium through L-type calcium channels. ${ }^{18}$ Moreover, the cytosolic calcium 
concentration was significantly reduced in the absence of extracellular calcium, which was consistent with a previous report. ${ }^{13}$ On the other hand when calcium was depleted from ER stores, more than $60 \%$ of cells exhibited a calcium peak under the stimulation of fluid flow, similar with those observed in randomly cultured 80-90\% confluent MC3T3-E1 cells under an oscillatory fluid flow. ${ }^{1}$ The magnitude of the first responsive peak was not significantly altered. This confirmed that extracellular calcium influx was responsible for the initial calcium peak. However, the average number of responsive $\left[\mathrm{Ca}^{2+}\right]_{i}$ peaks in the cell network was significantly reduced to barely more than one. Thus ER stores appears to be the major calcium source responsible for the lower-magnitude $\left[\mathrm{Ca}^{2+}\right]_{i}$ peaks following the initial calcium transient in the network of bone cells. ${ }^{1,24}$

The $\left[\mathrm{Ca}^{2+}\right]_{\mathrm{i}}$ responses of the networked bone cells consist of a large initial peak followed subsequently by multiple lower-magnitude peaks, which is similar to those observed in an 80 $90 \%$ confluent bone cell-culture study. ${ }^{7}$ In the untreated group, over $50 \%$ of the cells were able to generate three or more calcium peaks within $9 \mathrm{~min}$. In the ER calcium depleted group, the ATP activation blocked group, and the gap junction blocked group, the average number of calcium peaks during 9 min was significantly reduced, and the number for the first two groups was very close to one (TG and suramin treated, respectively). The importance of ER calcium stores in the multiple responsive $\left[\mathrm{Ca}^{2+}\right]_{\mathrm{i}}$ peaks ${ }^{1,24}$ has been confirmed in the current networked bone cells. This new bone cell network study suggests the critical importance of the ATP pathway in mediating multiple $\left[\mathrm{Ca}^{2+}\right]_{i}$ peaks of bone cells under steady fluid flow. This observation is consistent with literature where calcium wave propagation in bone cells induced by cell poking was influenced by the ATP pathway. ${ }^{16-18}$ We also noted that $18 \alpha$-GA (gap junction blocking) did not completely extinguish the multiple transients of bone cells, as $32 \%$ of cells responded more than once. This implied that a different pathway other than gap junction signal communication also plays a significant role in the multiple calcium peaks in the bone cell network. Indeed, inhibiting $\mathrm{COX}-2 / \mathrm{PGE}_{2}$ or nitric oxide pathways also slightly reduced the multiple calcium peaks of individual osteoblasts, which was similar to previous findings in other cell types. ${ }^{19,22,32,35} \mathrm{~A}$ previous study by $\mathrm{Li}$ et al. has shown that blocking the nitric oxide pathway can significantly reduce the refilling capability of intracellular calcium store, 20 thereby decreasing the occurrence of multiple transients.

Calcium signaling in bone cells can be propagated and amplified via intercellular gap junctions. 11,16-18,30 An interesting result from the gap-junction blocked group is the observation of a sustained high $\left[\mathrm{Ca}^{2+}\right]_{\mathrm{i}}$ evoked by the steady fluid flow following the initial calcium peak (Fig. 4). The exact mechanism for this calcium plateau will require further investigation. In bone cells, once the $\left[\mathrm{Ca}^{2+}\right]_{i}$ is elevated rapidly by both extracellular entry and ER release, the high concentration of intracellular calcium activates various plasma membrane calcium pumps to enhance the extrusion rate to terminate this toxic-high $\left[\mathrm{Ca}^{2+}\right]_{\mathrm{i}}$ level. ${ }^{26}$ It seems that the $18 \alpha$ GA dramatically impeded or retarded the function of these calcium pumps. For a large fraction of the cells in this group, the $\left[\mathrm{Ca}^{2+}\right]_{\mathrm{i}}$ never recovered to the initial resting level during the 9min loading duration. Cells in this group showed the lowest frequency of responders with two or more calcium spikes, and the cells that exhibited multiple transients were characterized by a significantly longer time between the first and the second spikes ( $t_{3}$ value). Qualitatively, the intercellular propagation of a $\left[\mathrm{Ca}^{2+}\right]_{\mathrm{i}}$ transient from within a bone cell to its neighboring cells in the network was observed in untreated group, and this was blocked by $18 \alpha$-GA. Therefore, the elevated $\left[\mathrm{Ca}^{2+}\right]_{\mathrm{i}}$ could be partially attributable to the retention of $\left[\mathrm{Ca}^{2+}\right]_{\mathrm{i}}$.

In summary, a thorough investigation of the spatiotemporal characteristics of $\left[\mathrm{Ca}^{2+}\right]_{i}$ signaling of bone cells in a controlled cell network under steady fluid flow was conducted. The effects of several candidate pathways potentially involved in inter/intra cellular calcium signaling were also studied. We confirmed that the major source for the rapid initial calcium transient under mechanical stimulation was attributable to the influx of extracellular calcium. The ER calcium 
stores and ATP pathways are responsible for the subsequent multiple calcium peaks. The intercellular gap junctions in the cell network demonstrated a significant influence on the $\left[\mathrm{Ca}^{2+}\right]_{\mathrm{i}}$ response. Bone cells in a gap junction-blocked network exhibited a sustained high calcium concentration after the triggering from fluid flow. It was also shown that the $\mathrm{PGE}_{2}$ and NO pathways were both involved to a lesser extent in the calcium signaling of the bone cell network.

For future studies, it would be interesting to repeat similar experiments on an osteocyte network. It will also be important to re-examine the calcium propagation waves in a bone cell network subjected to oscillatory fluid flow, or steady flow with magnitudes closer to physiological values (5-32 dynes $/ \mathrm{cm}^{2}$ instead of 40 dynes $/ \mathrm{cm}^{2}$ ). A relatively high magnitude of shear stress was used in the current study to evoke more responding cells and more multiple calcium peaks. With the techniques presented in this study, it is also possible to examine the intercellular signaling between osteocytes and osteoblasts in a controlled cell network, or to build a 3D microfluidic system to mimic the in vivo fluid flow stimulation on osteocytes and their processes. ${ }^{33}$ To better understand the exact roles of individual pathways on calcium signaling, techniques that employ greater specificity such as the use of primary cells from gene knockout mice can be incorporated. Currently a theoretical model to predict the calcium responses in a gap junction connected/blocked cell network is under development in our laboratory.

\section{Acknowledgments}

This work was supported by NIH grant R21 AR052417 (X. Edward Guo). The authors wish to thank Mr. Andrew D. Baik for editing of this paper.

\section{REFERENCES}

1. Batra NN, Li YJ, Yellowley CE, You L, Malone AM, Kim CH, Jacobs CR. Effects of short-term recovery periods on fluid-induced signaling in osteoblastic cells. J. Biomech 2005;38:1909-1917. [PubMed: 16023480]

2. Berridge MJ. Inositol trisphosphate and calcium signalling. Nature 1993;361:315-325. [PubMed: 8381210]

3. Berridge MJ, Lipp P, Bootman MD. The versatility and universality of calcium signalling. Nat. Rev. Mol. Cell Biol 2000;1:11-21. [PubMed: 11413485]

4. Chen NX, Ryder KD, Pavalko FM, Turner CH, Burr DB, Qiu J, Duncan RL. Ca ${ }^{2+}$ regulates fluid shear-induced cytoskeletal reorganization and gene expression in osteoblasts. Am. J. Physiol. Cell Physiol 2000;278:C989-997. [PubMed: 10794673]

5. Clapham DE. Calcium signaling. Cell 1995;80:259-268. [PubMed: 7834745]

6. Cowin SC. On mechanosensation in bone under microgravity. Bone 1998;22:119S-125S. [PubMed: 9600767]

7. Donahue SW, Donahue HJ, Jacobs CR. Osteoblastic cells have refractory periods for fluid-flowinduced intracellular calcium oscillations for short bouts of flow and display multiple low-magnitude oscillations during long-term flow. J. Biomech 2003;36:35-43. [PubMed: 12485636]

8. Genetos DC, Geist DJ, Liu D, Donahue HJ, Duncan RL. Fluid shear-induced ATP secretion mediates prostaglandin release in MC3T3-E1 osteoblasts. J. Bone Miner. Res 2005;20:41-49. [PubMed: 15619668]

9. Genetos DC, Kephart CJ, Zhang Y, Yellowley CE, Donahue HJ. Oscillating fluid flow activation of gap junction hemichannels induces ATP release from MLO-Y4 osteocytes. J Cell Physiol 2007;212:207-214. [PubMed: 17301958]

10. Godin LM, Suzuki S, Jacobs CR, Donahue HJ, Donahue SW. Mechanically induced intracellular calcium waves in osteoblasts demonstrate calcium fingerprints in bone cell mechanotransduction. Biomech. Model Mechanobiol 2007;6:391-398. [PubMed: 17082961] 
11. Guo XE, Takai E, Jiang X, Xu Q, Whitesides GM, Yardley JT, Hung CT, Chow EM, Hantschel T, Costa KD. Intracellular calcium waves in bone cell networks under single cell nanoindentation. Mol. Cell. Biomech 2006;3:95-107. [PubMed: 17263256]

12. Guo Y, Martinez-Williams C, Gilbert KA, Rannels DE. Inhibition of gap junction communication in alveolar epithelial cells by 18alpha-glycyrrhetinic acid. Am. J. Physiol 1999;276:L1018-1026. [PubMed: 10362727]

13. Hung CT, Allen FD, Mansfield KD, Shapiro IM. Extracellular ATP modulates $\left[\mathrm{Ca}^{2+}\right]_{\mathrm{i}}$ in retinoic acid-treated embryonic chondrocytes. Am. J. Physiol 1997;272:C1611-1617. [PubMed: 9176153]

14. Hung CT, Allen FD, Pollack SR, Brighton CT. Intracellular $\mathrm{Ca}^{2+}$ stores and extracellular $\mathrm{Ca}^{2+}$ are required in the real-time $\mathrm{Ca}^{2+}$ response of bone cells experiencing fluid flow. J. Biomech 1996;29:1411-1417. [PubMed: 8894921]

15. Iqbal J, Zaidi M. Molecular regulation of mechanotransduction. Biochem. Biophys. Res. Commun 2005;328:751-755. [PubMed: 15694410]

16. Jorgensen NR, Geist ST, Civitelli R, Steinberg TH. ATP- and gap junction-dependent intercellular calcium signaling in osteoblastic cells. J. Cell Biol 1997;139:497-506. [PubMed: 9334351]

17. Jorgensen NR, Henriksen Z, Brot C, Eriksen EF, Sorensen OH, Civitelli R, Steinberg TH. Human osteoblastic cells propagate intercellular calcium signals by two different mechanisms. J. Bone Miner. Res 2000;15:1024-1032. [PubMed: 10841171]

18. Jorgensen NR, Teilmann SC, Henriksen Z, Civitelli R, Sorensen OH, Steinberg TH. Activation of Ltype calcium channels is required for gap junction-mediated intercellular calcium signaling in osteoblastic cells. J. Biol. Chem 2003;278:4082-4086. [PubMed: 12446698]

19. Krieger NS, Frick KK, Strutz K. LaPlante, Michalenka A, Bushinsky DA. Regulation of COX-2 mediates acid-induced bone calcium efflux in vitro. J. Bone Miner. Res 2007;22:907-917. [PubMed: 17352658]

20. Li N, Sul JY, Haydon PG. A calcium-induced calcium influx factor, nitric oxide, modulates the refilling of calcium stores in astrocytes. J. Neurosci 2003;23:10302-10310. [PubMed: 14614089]

21. Liedert A, Kaspar D, Blakytny R, Claes L, Ignatius A. Signal transduction pathways involved in mechanotransduction in bone cells. Biochem. Biophys. Res. Commun 2006;349:1-5. [PubMed: 16930556]

22. Looms DK, Tritsaris K, Nauntofte B, Dissing S. Nitric oxide and cGMP activate $\mathrm{Ca}^{2+}$-release processes in rat parotid acinar cells. Biochem. J 2001;355:87-95. [PubMed: 11256952]

23. McGarry JG, Klein-Nulend J, Prendergast PJ. The effect of cytoskeletal disruption on pulsatile fluid flow-induced nitric oxide and prostaglandin E2 release in osteocytes and osteoblasts. Biochem. Biophys. Res. Commun 2005;330:341-348. [PubMed: 15781270]

24. Mogami H, Tepikin AV, Petersen $\mathrm{OH}$. Termination of cytosolic $\mathrm{Ca}^{2+}$ signals: $\mathrm{Ca}^{2+}$ reuptake into intracellular stores is regulated by the free $\mathrm{Ca}^{2+}$ concentration in the store lumen. EMBO $\mathrm{J}$ 1998;17:435-442. [PubMed: 9430635]

25. Norvell SM, Ponik SM, Bowen DK, Gerard R, Pavalko FM. Fluid shear stress induction of COX-2 protein and prostaglandin release in cultured MC3T3-E1 osteoblasts does not require intact microfilaments or microtubules. J. Appl. Physiol 2004;96:957-966. [PubMed: 14617531]

26. Pozzan T, Rizzuto R, Volpe P, Meldolesi J. Molecular and cellular physiology of intracellular calcium stores. Physiol. Rev 1994;74:595-636. [PubMed: 8036248]

27. Ralston SH, Todd D, Helfrich M, Benjamin N, Grabowski PS. Human osteoblast-like cells produce nitric oxide and express inducible nitric oxide synthase. Endocrinology 1994;135:330-336. [PubMed: 7516867]

28. Rubin J, Rubin C, Jacobs CR. Molecular pathways mediating mechanical signaling in bone. Gene 2006;367:1-16. [PubMed: 16361069]

29. Sato K, Suematsu A, Nakashima T, Takemoto-Kimura S, Aoki K, Morishita Y, Asahara H, Ohya K, Yamaguchi A, Takai T, Kodama T, Chatila TA, Bito H, Takayanagi H. Regulation of osteoclast differentiation and function by the CaMK-CREB pathway. Nat. Med 2006;12:1410-1416. [PubMed: 17128269]

30. Saunders MM, You J, Trosko JE, Yamasaki H, Li Z, Donahue HJ, Jacobs CR. Gap junctions and fluid flow response in MC3T3-E1 cells. Am. J. Physiol. Cell Physiol 2001;281:C1917-C1925. [PubMed: 11698250] 
31. Shapiro F. Variable conformation of GAP junctions linking bone cells: a transmission electron microscopic study of linear, stacked linear, curvilinear, oval, and annular junctions. Calcif. Tissue Int 1997;61:285-293. [PubMed: 9312198]

32. Soldati L, Terranegra A, Baggio B, Biasion R, Arcidiacono T, Priante G, Cusi D, Vezzoli G. Arachidonic acid influences intracellular calcium handling in human osteoblasts. Prostaglandins Leukot. Essent. Fatty Acids 2006;75:91-96. [PubMed: 16870415]

33. Takai, E. Modulation of bone cell mechanotransduction. Columbia University; New York: 2005. p. 209Department of Biomedical Engineering

34. Vashishth D, Verborgt O, Divine G, Schaffler MB, Fyhrie DP. Decline in osteocyte lacunar density in human cortical bone is associated with accumulation of microcracks with age. Bone 2000;26:375380. [PubMed: 10719281]

35. Volk T, Mading K, Hensel M, Kox WJ. Nitric oxide induces transient $\mathrm{Ca}^{2+}$ changes in endothelial cells independent of cGMP. J. Cell Physiol 1997;172:296-305. [PubMed: 9284949]

36. Weinbaum S, Cowin SC, Zeng Y. A model for the excitation of osteocytes by mechanical loadinginduced bone fluid shear stresses. J. Biomech 1994;27:339-360. [PubMed: 8051194]

37. Yellowley CE, Jacobs CR, Donahue HJ. Mechanisms contributing to fluid-flow-induced $\mathrm{Ca}^{2+}$ mobilization in articular chondrocytes. J. Cell Physiol 1999;180:402-408. [PubMed: 10430180]

38. Yellowley CE, Li Z, Zhou Z, Jacobs CR, Donahue HJ. Functional gap junctions between osteocytic and osteoblastic cells. J. Bone Miner. Res 2000;15:209-217. [PubMed: 10703922]

39. You LD, Weinbaum S, Cowin SC, Schaffler MB. Ultrastructure of the osteocyte process and its pericellular matrix. Anat. Rec. A Discov. Mol. Cell Evol. Biol 2004;278:505-513. [PubMed: 15164337]

40. Zaman G, Pitsillides AA, Rawlinson SC, Suswillo RF, Mosley JR, Cheng MZ, Platts LA, Hukkanen M, Polak JM, Lanyon LE. Mechanical strain stimulates nitric oxide production by rapid activation of endothelial nitric oxide synthase in osteocytes. J. Bone Miner. Res 1999;14:1123-1131. [PubMed: 10404012]

41. Zayzafoon M. Calcium/calmodulin signaling controls osteoblast growth and differentiation. J. Cell Biochem 2006;97:56-70. [PubMed: 16229015]

42. Zayzafoon M, Fulzele K, McDonald JM. Calmodulin and calmodulin-dependent kinase IIalpha regulate osteoblast differentiation by controlling c-fos expression. J. Biol. Chem 2005;280:70497059. [PubMed: 15590632] 


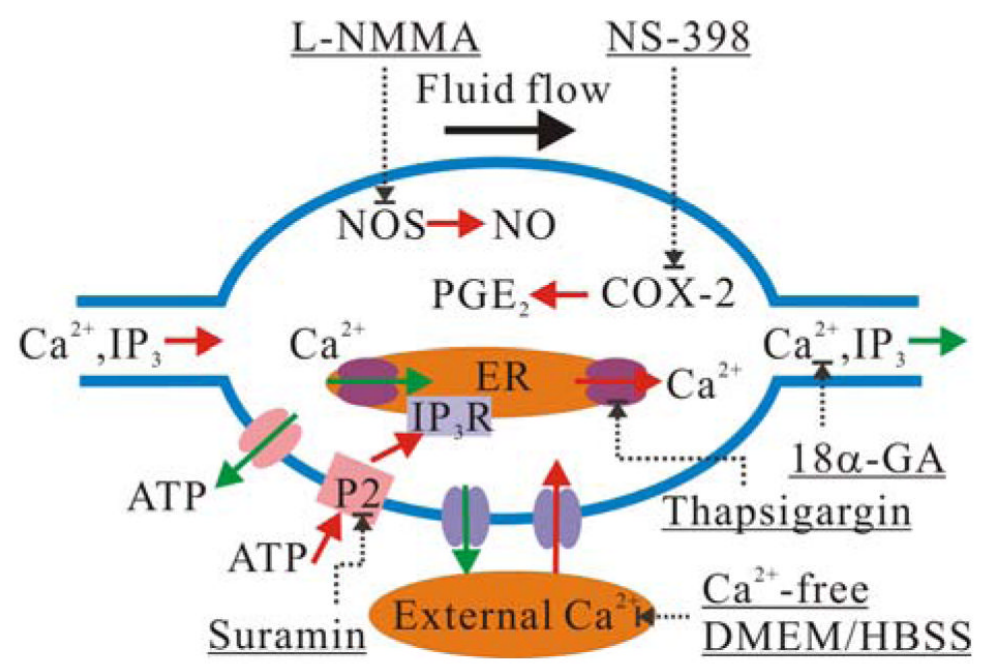

FIGURE 1.

A schematic drawing of calcium signaling pathways in bone cells and corresponding inhibitors employed in the current study. Red arrow: influx or upregulation activity, green arrow: efflux from cytosol, dash arrow: inhibition or blocking with a specific inhibitory intervention noted and underlined. 

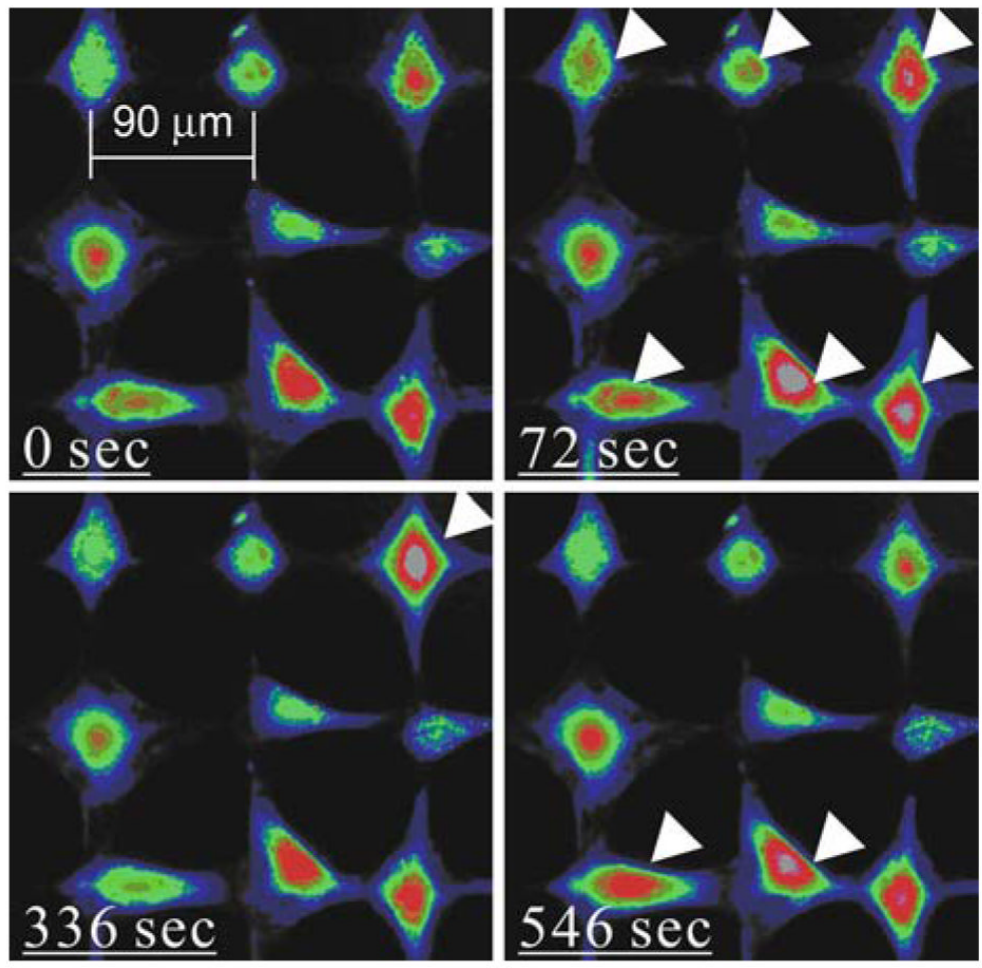

FIGURE 2.

Pseudo-color images of typical intracellular calcium responses of a bone cell network from untreated group. Fluid flow was applied at $60 \mathrm{~s}$. Arrowheads highlight those cells responding. Some cells were able to respond multiple times. 


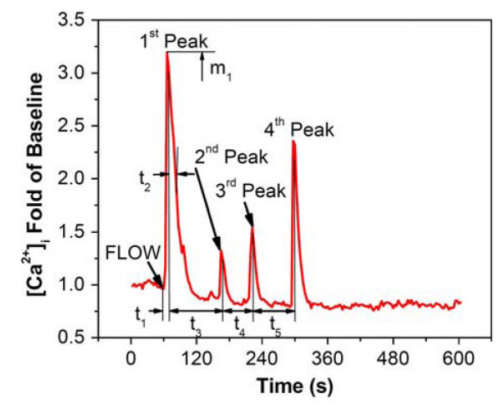

FIGURE 3.

A typical calcium response of bone cells in an untreated network under applied steady fluid flow. The characteristic temporal parameters are also illustrated. $t_{1}$ denotes the time from flow onset to the maximum value of the first responsive peak; $t_{2}$ is the time from peak value to the $50 \%$ relaxation; $t_{3}, t_{4}$, and $t_{5}$ are the time intervals between different peaks. $m_{1}$ represents the normalized magnitude of the first peak. 


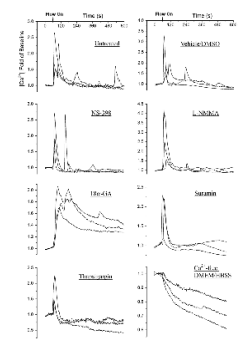

FIGURE 4.

A set of typical intracellular calcium traces of individual cells with or without pharmacological blocker treatment. The calcium images were recorded for $10 \mathrm{~min}(1 \mathrm{~min}$ for baseline and $9 \mathrm{~min}$ for flow stimulation). The intensity of intracellular calcium concentration shown here was normalized to the baseline. 

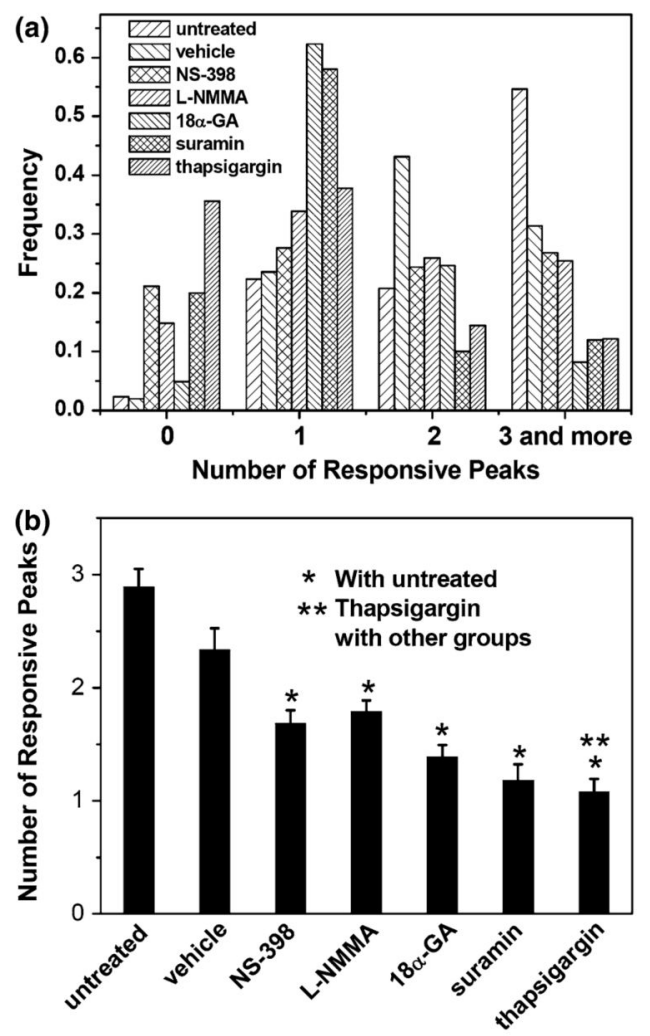

FIGURE 5.

(a) The frequency distribution of the number of responsive peaks of cells in different groups and (b) the average of the number of responsive peaks (the error bars are standard errors of the means (SEM) while * and $* *$ indicate statistical significance of $p<0.05)$. The group of $\mathrm{Ca}^{2+}$ free medium had no response to fluid flow and was not included. 

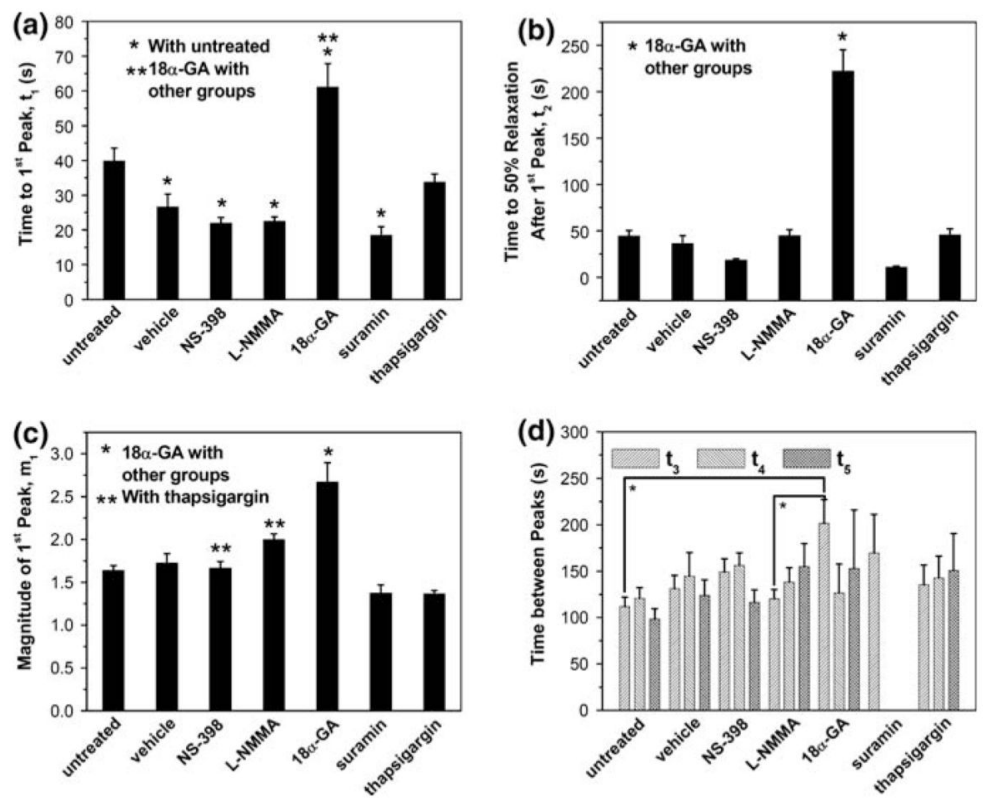

FIGURE 6.

Network characteristic parameters of calcium response in the bone cell network under steady fluid flow from different treatment groups (the error bars are SEM while * and ** indicate statistical significance of $p<0.05$ ): (a) time to the first peak $t_{1}$; (b) time to $50 \%$ relaxation after the first peak $t_{2}$; (c) magnitude of the first peak $m_{1}$; and (d) time between peaks $t_{3}$, $t_{4}$, and $t_{5}$. The group of $\mathrm{Ca}^{2+}$ free medium had no response to fluid flow and was not included. 